\title{
KAJIAN HISTORIS KUMPULAN PUISI TIRANI DAN BENTENG KARYA TAUFIQ ISMAIL
}

\author{
Martalena \\ marta lena17@yahoo.com \\ Guru Madrasah Tsanawiyah Negeri Manna Bengkulu Selatan
}

\begin{abstract}
The purpose of this research aim to know the representation of historical event and historical fact in Tirani dan Benteng poem anthology by Taufiq Ismail. The background of the study was the researcher's interest on poems by Taufiq Ismail which were anthology in Tirani and Benteng. The poems told about the historical events at the end of Soekarno era. This study used historical approach. The method used in this study was content analysis. The scope of the study was the analysis toward of the historical event representations and historical facts representation in the anthology. The focuses of this study were: (a) historical event representations, (b) artifact representations, (c) sociofact representation, and (d) mentifact representation. The results show that: (1) the event historical reprentations were: G30S/PKI event, collapse of Indonesian economic joint, event demonstration student in Tritura action causing to die Arief Rachman Hakim, (2) the artifact representations were: jacket covered with blod, rumpled banner, flag at half mast, weapon and steel bayonet, (3) sociofact representations were poverty and vertical as well as horizontal class conflicts, (4) mentifact representations were the spirit to defend truth and justice and the aspiration of the youths involved in Tritura action.
\end{abstract}

Keywords: historical study, poem, representation, historical fact, social fact

\section{PENDAHULUAN}

Fakta-fakta sejarah dalam sastra seringkali dijumpai pada karya-karya yang dianggap sebagai sastra sejarah. Dalam hal ini peristiwa-peristiwa sejarah dipakai secara sengaja ataupun tidak sengaja oleh penulisnya sebagai unsur pembangun karya tersebut. Namun perlu disadari, meskipun dalam sebuah karya sastra terdapat unsur-unsur sejarah, di dalam karya sastra akan selalu ada unsur fiksi atau imajinasi. Unsur imajinasi merupakan unsur utama yang menjadi penanda sebuah cipta sastra. Pembacalah yang kemudian menentukan apakah di dalam sebuah karya sastra terkandung fakta-fakta sejarah atau tidak.
Puisi merupakan salah satu genre sastra di samping novel, cerpen dan drama. Menurut Aminuddin (2010:171) sebagai salah satu genre sastra, puisi, tidak hanya mengandung nilai-nilai kehidupan, sosialpsikologis, juga mengandung nilai-nilai kesejarahan. Oleh sebab itu, lewat puisi seringkali pembaca dapat menemukan unsur-unsur historis yang berkaitan dengan zaman saat puisi itu dilahirkan. Hal tersebut didukung oleh Aminuddin (2010: 174) yang mengatakan, terdapat hubungan timbal balik antara peristiwa kesejarahan dengan gagasan yang terdapat dalam puisi, di satu sisi, puisi dapat mengambil peristiwa-peristiwa penting yang berhubungan dengan kehidupan suatu negara, suatu bangsa, dan masalah 
politik pada suatu masa tertentu. Pada sisi lain, puisi mampu menggambarkan kembali peristiwa-peristiwa tersebut serta mampu mengabadikannya untuk dibaca dan dipahami di masa kemudian.

Salah satu buku kumpulan puisi yang menarik untuk dikaji unsur kesejarahannya adalah buku Tirani dan Benteng karya Taufiq Ismail. Buku ini penulis yakini memuat fakta-fakta sejarah bangsa Indonesia, terutama sejarah perjuangan yang terjadi antara tahun 1960 sampai 1966. Hal ini sesuai dengan tahun-tahun penulisan puisi. Berdasarkan observasi awal yang penulis lakukan, di dalam buku ini ditemukan fenomena sejarah bangsa Indonesia yang erat kaitannya dengan pergolakan yang terjadi di akhir masa pemerintahan Soekarno. Fenomena sejarah yang muncul berbentuk gambaran tentang kondisi sosial masyarakat Indonesia yang diwarnai keprihatinan, kemiskinan, dan kesengsaraan, serta iklim politik yang labil pada masa transisi pemerintahan Orde Lama menuju Orde Baru.

Di kulit belakang buku Tirani dan Benteng, J.S. Hadis memberikan komentar, "Tirani meskipun kalau ia punya kelemahan sebagai sajak-sajak yang berdiri sendiri karena bersifat fragmentaris, bernafas pendek atau tidak selesai, namun sebagai kumpulan sajak ia merupakan snapshot tajam dari periode sejarah sebagai peristiwa maupun sebagai kisah. Karena periode sejarah yang direkamnya justru pada sebuah titik penyimpangan, penyimpangan dari suatu orde ke lain orde yang baru."

Komentar senada juga disampaikan oleh Mochtar Lubis, yang berbunyi, "Ketika saya membacanya untuk pertama kali di rumah tahanan
Jalan Keagungan Jakarta, saya merasa seakan angin segar datang menghembuskan melenyapkan kegelapan yang ditimbulkan dalam relung-relung kalbu manusia Indonesia oleh tirani seratus menteri".

Dalam esai yang dimuat di majalah Horison, (Hadi, Juli 2008: 13-14) menyatakan, kekuatan lain yang dijumpai dalam sajak Taufiq Ismail ialah kecermatan penyair ini menangkap dan menggambarkan momen penting sejarah melalui pengamatan dan keterlibatannya secara langsung.

Dalam upaya memahami puisipuisi Taufiq Ismail dalam Tirani dan Benteng, pemahaman yang dilakukan tidak dapat dilepaskan dari konteks sosial budaya dan latar belakang peristiwa kesejarahan yang terjadi pada tahun-tahun penulisannya. Sebab, menurut Teeuw (dalam Sayuti, 2008: 373, 379 dan Pradopo, 2009: 125) teks puisi kapan pun diciptakan tidak mungkin lahir dari situasi kekosongan budaya.

Menurut Dilthey (dalam Rafiek, 2012: 23) untuk menafsirkan ekspresi hidup manusia yang berkaitan dengan karya sastra membutuhkan tindakan pemahaman historis. Dalam tindakan pemahaman historis ini yang berperan adalah pengetahuan pribadi mengenai sesuatu yang dimaksudkan manusia.

Dengan demikian, Penelitian ini bertujuan mengetahui representasi peristiwa historis dan fakta-fakta historis dalam Tirani dan Benteng. Ruang lingkup penelitian ini mengkaji representasi peristiwa historis dan representasi faktafakta historis yang terdapat dalam Tirani dan Benteng. Representasi peristiwa historis yang akan dikaji meliputi representasi peristiwa historis yang 
melatarbelakangi lahirnya puisi, sedangkan representasi fakta-fakta historis yang akan dikaji adalah: (a) representasi fakta-fakta benda (artifact), (b) representasi fakta-fakta sosial (sociofact), dan (3) representasi faktafakta mental (mentifact).

\section{METODE PENELITIAN}

Metode yang digunakan adalah metode analisis isi (content analysis). Menurut Ratna (2009: 48), Metode ini terdiri atas dua macam, yaitu isi laten dan isi komunikasi. Isi laten adalah isi yang terkandung dalam dokumen dan naskah, sedangkan isi komunikasi adalah pesan yang terkandung sebagai akibat komunikasi yang terjadi. Isi laten adalah isi sebagaimana yang dimaksudkan oleh penulis, sedangkan isi komunikasi adalah isi sebagaimana terwujud dalam hubungan naskah dengan konsumen. Sesuai dengan namanya analisis isi terutama berhubungan dengan isi komunikasi. Data yang dikumpulkan dalam penelitian ini berbentuk kutipan baris, bait dan pupuh. Hal ini mengacu kepada yang disampaikan Endraswara (2013: 162), jika data berupa puisi, unit data dapat berupa baris, bait dan pupuh (kesatuan bait). Analisis data penelitian ini menggunakan teknik analisis seperti yang sudah dilakukan Ratna (2009) dan Endraswara (2013).

\section{HASIL DAN PEMBAHASAN}

\section{a. Gambaran Umum Isi Buku Tirani dan Benteng}

Buku kumpulan puisi Tirani dan Benteng terdiri atas tiga sub-judul. Pertama, Puisi-Puisi Menjelang Tirani dan Benteng, kedua, Tirani, dan ketiga,
Benteng. Dalam sub-judul Puisi-puisi Menjelang Tirani dan Benteng, terdapat 32 judul puisi. Dalamsub-judul Tirani, terdapat 18 judul puisi. Dalam Benteng, terdapat 22 judul puisi. Jumlah keseluruhan puisi adalah 72 judul. Puisipuisi tersebut ditulis oleh Taufiq Ismail dalam rentangan waktu tahun antara 1960 sampai 1966. Hal ini diketahui berdasarkan angka tahun yang dicantumkan pengarangnya pada bagian bawah setiap puisi.

Dari 72 judul puisi itu, yang dijadikan sebagai data penelitian ini adalah sebanyak 27 puisi. 27 puisi itu ditemukan peristiwa historis dan atau fakta-fakta historis/fakta sosial. Berdasar pada 27 judul puisi yang dijadikan data penelitian, 6 judul di antaranya memuat peristiwa historis, 13 judul memuat fakta-fakta historis, dan 8 judul memuat peristiwa historis sekaligus memuat fakta-fakta historis. Selain itu, dalam Tirani dan Benteng juga ditemukan 48 foto yang bersifat dokumentasi yang berkaitan dengan latar belakang peristiwa sejarah ketika puisi ditulis. Foto-foto tersebut merepresentasikan peristiwa historis yang terjadi di Indonesia ketika itu. Misalnya, foto tentang evakuasi jenazah para korban G3OS/PKI di Lubang Buaya, foto tentang suasana masyarakat yang sedang mengantre beras dan bahan makanan pokok lainnya tahun 1964/1965, serta foto tentang gegap gempita suasana demonstrasi mahasiswa (KAMI) dan pelajar (KAPPI) yang tergabung dalam Aksi Tritura tahun 1966.

\section{b. Representasi Peristiwa Historis dalam Tirani dan Benteng \\ Peristiwa historis yang direpresentasikan penyair dalam Tirani}


dan Benteng, yaitu: (1) peristiwa G30S/PKI, (2) melemahnya sendi perekonomian Indonesia, dan (3) peristiwa demonstrasi mahasiswa dalam aksi Tritura yang merenggut nyawa Arief Rachman Hakim.

Pertama, peristiwa G30S/PKI. Peristiwa ini digambarkan oleh penyair dalam puisi berjudul "Oktober Hitam", seperti tampak dalam larik-larik berikut:

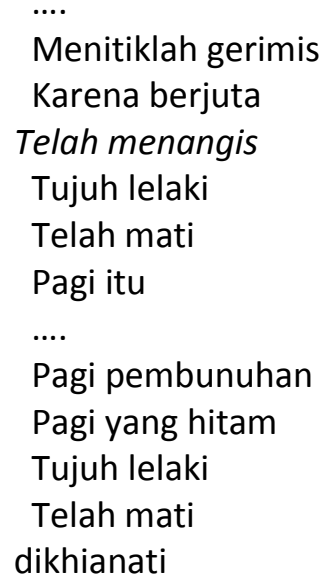

Judul, "Oktober Hitam", memberi petunjuk peristiwa itu terjadi di bulan Oktober. Diksi "hitam" melambangkan duka akibat kematian. Diksi "berjuta" menunjukkan duka itu dirasakan oleh berjuta orang Indonesia. Frase "Tujuh lelaki", merupakan simbol untuk tujuh orang perwira yang menjadi korban dalam peristiwa G30S/PKI. Jadi, peristiwa yang terjadi di bulan Oktober tersebut, mengacu kepada peristiwa G30S/PKI tahun 1965.

Peristiwa G30S/PKI yang disampaikan secara simbolik dalam Tirani dan Benteng mengingatkan pembaca tentang trauma sejarah yang kuat menggores hati rakyat Indonesia. Setelah pemerintahan Orde Lama tumbang, yang kemudian digantikan oleh pemerintahan Orde Baru, PKI menjadi momok dan dianggap sebagai bahaya laten yang akan selalu menghantui dan mengancam ketenangan rakyat Indonesia, sehingga ancamannya tetap harus diwaspadai. Pemerintahan Soeharto di masa Orde Baru merepresentasikan peristiwa G30S/PKI dalam sebuah film yang wajib ditonton oleh anak-anak sekolah.

Kedua, peristiwa melemahnya sendi perekonomian Indonesia. Peristiwa ditemukan pada puisi berjudul "Catatan Tahun 1965". Penyair melukiskan peristiwa tersebut dalam larik-larik berikut:

\section{Minyak tanah dikemanakan \\ Rebutan beras antrian \\ Siapa mati kelaparan \\ Inflasi saban pagi \\ (Tirani dan Benteng, hal 52)}

Larik "Rebutan beras antrian", mengandung makna masyarakat sedang menghadapi krisis pangan. Persediaan kebutuhan pokok sangat langka, sehingga untuk memenuhi kebutuhan tersebut, masyarakat terpaksa berdiri dalam antrian panjang dan melelahkan.

Ketiga, peristiwa demonstrasi mahasiswa dalam Aksi Tritura yang merenggut nyawa Arief Rachman Hakim. Peristiwa. ini direpresentasikan oleh penyair dalam 11 puisi yang berjudul: "Dari catatan Seorang Demonstran, Sebuah Jaket Berlumur Darah, Jalan Segara, Karangan Bunga, Depan Sekretariat Negara, Harmoni, Seorang Tukang Rambutan Pada Istrinya, Benteng, Yell, Horison, Percakapan Angkasa, dan Salemba.

Merujuk pada sejarah, Pusponegoro, dkk (2010: 547) mengatakan pada tanggal 24 Februari 1966, saat pelantikan menteri kabinet baru, para demonstran melakukan aksi 
serentak mengempiskan ban-ban mobil di jala-jalan raya di seluruh ibu kota sehingga lalu lintas praktis terhenti. Dalam bentrokan di depan istana, seorang demonstran yang bernama Arief Rachman Hakim, mahasiswa Universitas Indonesia, gugur terkena peluru Resimen Cakrabirawa. Peristiwa duka itu dilukiskan oleh Taufiq dalam larik-larik berikut:

\author{
Jalan Segara \\ Di sinilah penembakan \\ Kepengecutan \\ Dilakukan \\ .... \\ Dan pelor pembayar pajak \\ Negeri ini \\ Ditembuskan ke punggung \\ Anak-anaknya sendiri \\ (Tirani dan Benteng, hal 73)

\section{Horison} \\ Karena Arif telah gugur \\ Dan luka-luka dua puluh satu \\ (Tirani dan Benteng, hal 135)
}

\section{c. Representasi Fakta Benda (Artifact) dalam Tirani dan Benteng}

Representasi Fakta benda yang ditemukan dalam Tirani dan Benteng menjadi petunjuk sekaligus bukti telah terjadi peristiwa sejarah. Fakta-benda yang ditemukan adalah: (1) jaket berlumur darah, (2) spanduk kumal, (3) bendera setengah tiang, dan (4) senjata dan sangkur baja.

Pertama, jaket berlumur darah. Fakta benda ini digubah secara simbolik oleh penyair dalam puisi berjudul "Sebuah Jaket Berlumur Darah", berikut adalah kutipan larik-lariknya:
Sebuah jaket berlumur darah

Kami semua telah menatapmu

Telah berbagi duka yang agung

Dalam kepedigan bertahun-tahun

(Tirani dan Benteng, hal 67)

"jaket berlumur darah" mengacu kepada jaket yang dikenakan oleh Arief Rachman Hakim ketika tertembak dalam aksi Tritura.

Kedua, spanduk. Fakta benda ini terlihat pada kutipan larik-larik berikut:

\section{Spanduk kumal itu, ya spanduk itu Kami semua telah menatapmu (Tirani dan Benteng, hal 67)}

Frase "spanduk kumal", dapat diinterpretasikan sebagai perjuangan atau aspirasi yang disampaikan oleh pemuda-pemudi Indonesia. Perjuangan atau aspirasi itu sudah lama dipendam dalam hati masyarakat Indonesia.

Ketiga, bendera setengah tiang. Representasi fakta benda dalam bentuk bendera setengah tiang, tampak dalam kutipan berikut:

Dan di atas bangunan-bangunan Menunduk bendera setengah tiang (Tirani dan Benteng, hal 67)

Frase "bendera setengah tiang", merupakan diksi yang dipilih oleh penyair sebagai simbol untuk mengungkapkan rasa duka yang dialami rakyat atas gugurnya seorang pembela kebenaran.

Keempat, senjata dan sangkur baja. Fakta benda dalam bentuk "senjata" ditemukan dalam empat judul puisi, yaitu: Sebuah Jaket Berlumur Darah, Harmoni, Jalan Segara, dan, Dari Ibu Seorang Demonstran. Berikut adalah salah satu kutipan puisinya: 
Sebuah sungai membatasi kita

Di bawah terik matahari Jakarta kebebasan dan penindasan

Berlapis senjata dan sangkur baja

(Tirani dan Benteng, hal 67)

Pada larik ketiga terdapat dua diksi yang maknanya saling berlawanan, yaitu, diksi "kebebasan", dan "penindasan". Diksi "kebebasan" mengandung makna "kemerdekaan", dan diksi 'penindasan" mengandung makna "hilangnya kemerdekaan".

Dapat ditafsirkan, saat itu Indonesia sudah merdeka, namun kemerdekaan itu belum sepenuhnya dirasakan oleh bangsa Indonesia. Masyarakat yang benar-benar ingin merasakan kemerdekaan masih harus berhadapan dengan "senjata", dan "sangkur baja", yang digunakan oleh pemerintah.

\section{d. Representasi Fakta Sosial (Sociofact) dalam Tirani dan Benteng}

Walaupun karya sastra tidak selalu bisa diperlakukan sebagai dokumen sosial budaya, karya sastra selalu memanfaatkan dan/atau menanggapi kenyataan-kenyataan sosial budaya. Bahkan dapat dikatakan bahwa karya sastra selalu melukiskan suatu kenyataan sosial budaya meskipun cara pelukisannya metaforis dan atau simbolis (Saryono, 2009: 158).

Tirani dan Benteng adalah sebuah dokumen tertulis yang di dalamnya dapat ditemukan representasi faktafakta sosial masyarakat Indonesia. Faktafakta sosial yang ditemukan adalah: (1) kemiskinan, dan (2) Pertentangan kelas.

Pertama, kemiskinan. Fakta kemiskinan digambarkan dalam lima judul puisi, yaitu: "Syair Orang Lapar,
Alamat Tak Dikenal, Bukit Biru Bukit Kelu, Catatan Tahun 1965", dan, Silhuet". Dalam puisi "Syair Orang Lapar," terdapat deskripsi mengenai kondisi kemiskinan yang menyerang hampir seluruh pelosok negeri. Puisi ini ditulis tahun 1964 yang sekaligus sebagai petunjuk waktu terjadinya kondisi tersebut. Misalnya tampak pada lariklarik berikut:

Lapar menyerang desaku

Kentang dipanggang kemarau

Surat orang kampungku

Kuguratkan kertas

Risau

(Tirani dan Benteng, hal 33)

Kutipan tersebut secara konkret mendeskripsikan betapa berat kepedihan dan kesengsaraan ditimbulkan oleh kemiskinan.

Kedua, pertentangan Kelas. Pertentangan kelas yang ditemukan ada dua macam, yaitu pertentangan kelas secara horizontal, yang terjadi antar golongan dalam lapisan masyarakat, yang disebut juga sebagai konflik horizontal, dan pertentangan kelas secara vertikal, yang terjadi antara kelas bawah dan kelas atas, yaitu antara pemerintah dan masyarakat, yang disebut juga sebagai konflik vertikal.

Konflik horizontal yang ditemukan dalam Tirani dan Benteng adalah perpecahan yang terjadi di kalangan para seniman dan budayawan Indonesia. Seperti yang tercatat dalam sejarah, saat itu terdapat dua kubu seniman yang menganut paham saling berseberangan. Kubu pertama adalah kelompok seniman "Lekra", yang menganut paham pro-PKI, dan kubu kedua, kelompok seniman dan cendikiawan "Manifes Kebudayaan" atau yang disingkat "Manikebu", yang menganut paham humanisme universal, 
yang sekaligus menentang PKI. Pertikaian antara dua kubu seniman itu tergambar dalam kutipan puisi berikut:

$$
\begin{aligned}
& \text { Hamka diludahi Pram } \\
& \text { Masuk penjara Sukabumi } \\
& \text { Jassin dicaci diserapahi } \\
& \text { Terbenam daftar hitam } \\
& \text { Usmar dimaki Lentera } \\
& \text { Takdir disumpahi Lekra } \\
& \text { Sudjono dicangkul BTI } \\
& \text { Nasakom bersatu apa } \\
& \text { Umat dibunuh di desa } \\
& \text { Kanigoro bagaimana lupa } \\
& \text { Kus bersaudara dipenjara } \\
& \text { Osram bungkuk meringkuk } \\
& \text { (Tirani dan Benteng, hal 52) }
\end{aligned}
$$

Disebutkan secara konkret beberapa nama seniman atau sastrawan Manikebu, seperti Hamka, Jassin, Usmar, dan Takdir, yang menjadi sasaran atas serangan yang dilakukan oleh sastrawan pro-PKI. Simbol-simbol sastrawan pro-PKI muncul dalam diksi: Pram, Lentera, Lekra, dan BTI. Pihak yang disudutkan atau sebagai korban adalah seniman dari kelompok Manikebu.

Tahun 1966, yaitu tahun menandai runtuhnya kekuasaan Orde Lama, adalah kulminasi kekacauan politik dari kekacauan-kekacauan sebelumnya. Sejarah, sementara itu menunjukkan, dalam keadaan politik kacau justru jumlah orang yang terlibat politik makin banyak. Mereka adalah orang-orang Lekra pro komunis, dan orang-orang Manikebu sebagai tandingannya (Darma, Juli 2008: 19).

Fakta-fakta yang mengindikasikan terjadinya pertentangan kelas secara vertikal muncul dalam bentuk pertikaian antara rakyat dengan pemerintahan Soekarno. Kemunculannya dapat dilihat dalam tiga judul puisi, yaitu: "Silhuet, 22
Tahun Kemudian, Kemis Pagi, dan, Pengkhianatan Itu Terjadi pada Tanggal 9 Maret".

Dalam puisi berjudul "Silhuet", perlawanan rakyat terhadap pemerintah muncul dalam larik-larik berikut:

Di bawah bayangan pilar

Di bawah bayangan emas

Berjuta bayang-bayang

Menangisi gerimis

Menangisi gunung api

(Tirani dan Benteng, hal 122)

Puisi ini merupakan simbol untuk menyindir pemerintah. Makna Frase "bayangan pilar", dan frase "bayangan emas", mengacu kepada tugu Monas yang ketika itu baru didirikan oleh Soekarno. Tugu Monas dibangun dengan menelan anggaran negara yang sangat besar. Proyek itu dinilai telah menghamburkan uang negara tanpa kendali, dan tanpa memikirkan keadaan rakyat yang saat itu sedang kelaparan.

Pada puisi berjudul "22 Tahun Kemudian", perlawanan rakyat terhadap pemerintah tampak pada kutipan berikut:

Berjuta-juta kami berdiri. Lesu dan lunglai

Sehabis rapat besar dan pawai-pawai Yang tidak memikirkan pemborosan dan wabah penyakit Tidak membicarakan harga-harga dan nestapa

Kemiskinan

Pemborosan? Siapa peduli itu Harga? Harga apa? Apa harga diri kau?

(Tirani dan Benteng, hal 105) 
Kebijakan-kebijakan yang diambil oleh pemerintahan Soekarno dianggap tidak sesuai dengan aspirasi masyarakat. Bahkan, kebijakan-kebijakan itu banyak melukai hati rakyat Indonesia.

Mereka yang merencanakan seratus mahligai raksasa

Membeli benda-benda tanpa harga di manca-negara

Dan memperoleh uang emas beratus juta

Bagi diri sendiri, di bank-bank luar negeri

(Tirani dan Benteng, hal 141)

\section{e. Representasi Fakta Mental (mentifact) dalam Tirani dan Benteng}

Fakta mental yang ditemukan adalah: (1) semangat, dan (2) aspirasi.

Pertama, semangat. Pasca pemberontakan G30S/PKI terjadi krisis kepercayaan terhadap kepemimpinan Soekarno. Hal ini berdampak buruk terhadap segala aspek kehidupan masyarakat Indonesia. Kondisi ini kian meningkat hingga akhir tahun 1965. Hal itu memicu munculnya aksi ketidakpercayaan masyarakat terhadap kebijakan-kebijakan yang diambil oleh presiden Soekarno dalam menangani persoalan politik, keamanan, dan ekonomi. Aksi ketidakpercayaan berlanjut pada aksi melancarkan tuntutan-tuntutan yang muncul dalam bentuk gelombang semangat tak tertahan.

Representasi gelombang semangat itu terlihat pada 13 judul puisi, yaitu: "Oktober Hitam, Persetujuan, Sebuah Jaket Berlumur Darah, Horison, Mimbar, Rendez-vous, Kita Adalah Pemilik Sah Republik Ini, Seorang Tukang Rambutan pada Istrinya, dan, Benteng."
Pada puisi berjudul "Oktober Hitam," fakta mental dalam bentuk semangat muncul dalam larik-larik berikut:
Kami pun terjaga dalam Oktober yang hitam
Bangkit dari kabut ilusi
Tahun-tahun meleleh, tangan kan menegak keadilan
Dalam deram tak tertahan-tahan
(Tirani dan Benteng, hal 60)

Pada puisi berjudul "Persetujuan," gambaran semangat muncul dalam keinginan untuk berbuat dan bertindak menegakkan keadilan.

Momentum telah dicapai. Kita

Dalam estafet amat panjang

Menyebar benih di bumi ini

Telah lama berteguh hati

Adikku Kappi, engkau sangat muda

Mari kita berpacu dengan sejarah

Dan kini engkau di muka

(Tirani dan Benteng, hal 127)

Pada larik-larik tersebut terlihat semangat pemuda-pemudi Indonesia untuk berbuat dan bertindak menegakkan keadilan, yang muncul dalam larik, 'Momentum telah dicapai, Kita dalam estafet amat panjang", yang dapat ditafsirkan sebagai datangnya kesempatan dan waktu untuk berjuang menegakkan keadilan.

Diksi "terjaga", juga mengandung makna munculnya kesadaran dalam bentuk semangat. Semangat itu pun semakin kuat, yang dilukiskan dalam larik, "Tangan "kan menegak keadilan", dan larik, "Dalam deram tak tertahantahan".

Semangat para pemuda merupakan wakil dari semangat masyarakatnya. Dukungan masyarakat 
terhadap semangat para pemuda muncul pada puisi yang berjudul "Seorang Tukang Rambutan pada istriya".

Mereka kehausan dalam panas bukan main Terbakar di atas truk terbuka

Saya lemparkan sepuluh ikat rambutan kita, bu

Biarlah sepuluh ikat juga

Memang sudah rezeki mereka

(Tirani dan Benteng, Hal 110)

Tukang rambutan yang terdapat dalam puisi tersebut merupakan simbol dari masyarakat bawah, atau perwakilan dari rakyat jelata yang turut memberikan semangat kepada "mahasiswa, dan "anak-anak sekolah" yang sedang berjuang.

Kedua, aspirasi. Tirani dan Benteng berisi aspirasi dan pikiran-pikiran tentang kebebasan yang datang dari dalam jiwa yang sakit akibat ditekan oleh ketidakadilan. Aspirasi muncul dalam tiga judul puisi, yaitu: "Adalah Bel Kecil di Jendela, Beberapa Urusan Kita, dan, Kita Adalah Pemilik Sah Republik ini".

Mula-mula aspirasi itu hanya berbentuk aspirasi yang terpendam di dalam sanubari pemuda Indonesia, seperti yang tampak pada kutipan puisi berjudul, "Adalah Bel Kecil di Jendela" berikut ini:

Sebuah bel kecil tergantung di jendela

Di bulan Juni

Berkelining sepi

(Tirani dan Benteng, hal 44)

Frase "bel kecil", dapat ditafsirkan sebagi aspirasi, suara-suara, atau pemikiran. Diksi "jendela", adalah simbol untuk memandang dunia yang luas, dan "berkelining sepi", berarti aspirasi yang tidak tersampaikan.
Kemudian, aspirasi itu mencuat dalam bentuk aspirasi kolektif dari golongan intelektual muda Indonesia yang menggabungkan dirinya dalam berbagai kesatuan.Aspirasi itu kian membesar membentuk aspirasi masyarakat Indonesia. Hingga sampai pada puncaknya diluapkan dalam aksi demonstrasi menentang kebijakan pemerintahan Soekarno.

Orasi-orasi dilakukan oleh Kesatuan Aksi Mahasiswa Indonesia (KAMI), dan kemudian diikuti oleh Kesatuan Aksi Pemuda Pelajar Indonesia (KAPPI), serta kesatuan-kesatuan aksi lainnya. Gelombang aksi itu dikenal dengan aksi Tritura.

Dalam sejarah dicatat tiga macam aspirasi yang disampaikan pemuda dalam aksi Tritura, yaitu:

1. Bubarkan PKI

2. Retool Kabinet Dwikora

3. Turunkan harga/perbaiki ekonomi.

Tiga tuntutan itu merupakan aspirasi pemuda-pemudi Indonesia dalam upaya mendapatkan kehidupan yang lebih baik. Meskipun tiga kalimat tuntutan itu tidak dinyatakan secara tersurat dalam Tirani dan Benteng, namun, kemunculannya dalam bentuk simbol dapat dilihat pada puisi berjudul "Beberapa Urusan Kita", misalnya dalam larik puisi berikut ini:

Tentang nasib angkatan ini Itu urusan sejarah

Tapi tentang menegakkan keadilan Itu urusan kita

(Tirani dan Benteng, hal: 148)

Pada larik ke-3 dan ke-4, dinyatakan: "Tentang menegakkan keadilan itu urusan kita," yang mengandung makna sebagai pemikiran atau ajakan untuk berbuat dan bertindak 
demi tegaknya keadilan di bumi Indonesia.

Sayuti (2008: 372-373) mengatakan, Taufiq adalah tipe penyair yang sadar ketika pendekatan tajam dibungkam di media massa, ketika budaya akal sehat dikebiri, ketika waskat (pengawasan melekat) digerakkan bersamaan dengan korkat (korupsi melekat) - pinjam istilah Umar kayam - ketika berbagai hal dibuat univocal dan polifoni diharamkan, ketika kebinekaan dan pluralitas dibuat tidak berdaya, maka daya kreatif harus dapat diwujudkan lewat dan dalam seni (baca: puisi).

\section{SIMPULAN}

Kajian historis terhadap kumpulan puisi Tirani dan Benteng mengungkapkan bahwa puisi-puisi yang tergabung dalam Tirani dan Benteng ditulis oleh Taufiq Ismail karena terinspirasi oleh peristiwa sejarah yang sedang berlangsung di Indonesia sekitar tahun 1960-an. Puisi-puisi itu didukung dengan penggunaan simbol-simbol yang berkaitan dengan fakta-fakta sejarah yang terjadi di tanah air ketika itu. Hal itu terlihat dalam tema yang diusung disertai dengan penggunaan diksi yang menggambarkan kondisi dan simbolsimbol zaman yang sakit dan labil di tahun-tahun terakhir pemerintahan Soekarno.

\section{DAFTAR PUSTAKA}

Aminudin. 2010. Pengantar Apresiasi Karya Sastra. Bandung: Sinar Baru Algesindo.

Darma, Budi. Juli 2008. Individuasi Taufiq Ismail. Horison, hlm 23.

Endraswara, Suwardi. 2013. Metodologi Penelitian Sastra. Yogyakarta: CAPS.

Hadi, Abdul W.M. Juli 2008. Mengenal dan Menyelami Sajak-sajak Taufia Ismail. Horison, hlm 13-14.

Ismail, Taufiq. 2005. Tirani dan Benteng. Jakarta: Yayasan Indonesia.

Pradopo, Rahmat Djoko. 2009. Pengkajian Puisi. Yogyakarta: Gadjah Mada University Press.

Pusponegoro, dkk. 2010. Sejarah Nasional Indonesia Zaman Jepang dan Zaman Republik (cet-4 Edisi Pemutahiran). Jakarta: Balai Pustaka.

Rafiek, M. 2012. Teori Sastra. Bandung: PT. Rafika Aditama.

Ratna, Nyoman Kutha. 2009. Teori Metode dan Teknik Penelitian Sastra. Yogyakarta: Pustaka Pelajar.

Rosyidi, M Ikhwan, dkk. 2010. Analisis Teks Sastra. Yogyakarta: Graha Ilmu. 